\title{
Effect of Brine Calcium Concentration on the Surface Solubilization and Texture of Fresh Perline Mozzarella Cheese
}

\author{
Mustafa Öztürk ${ }^{1, a, *}$, Büşra Gülşah Güncï ${ }^{1, b}$ \\ ${ }^{1}$ Department of Food Engineering, Esentepe Campus, Sakarya University, 54000 Sakarya, Turkey \\ *Corresponding author \\ A R T I C L E IN F O A B S T R A C T \\ Research Article \\ Softening of cheese surface is a common problem especially in brined cheeses. In this study, the \\ effects of the brine calcium concentrations on the texture of fresh perline Mozzarella cheese were \\ investigated. The compositions of cheeses were analyzed 2 weeks after production. Brine protein \\ content were monitored at 2 and 4 week of storage. The effect of the brine calcium concentration \\ Received : 26/07/2020 \\ Accepted : 01/03/2021 \\ on the texture and meltability of cheeses were monitored Texture Profile Analysis (TPA) and \\ Schreiber meltability test at 2 and 4 weeks of storage. The decrease in brine calcium concentration \\ increased the protein transfer from cheese to brine, leading to an increase in the moisture content of \\ cheese. As the calcium concentration increased in brine, an increase in the hardness, and decrease \\ in adhesiveness and meltability of the cheeses were observed during storage. In conclusion, \\ Keywords: \\ softening/solubilization of the surface of fresh perline Mozzarella cheese can be prevented with \\ Fresh Mozzarella \\ increasing the brine calcium concentration.
}

Perline

Brine

Calcium

Texture

ozturkm@sakarya.edu.tr

\section{Introduction}

Fresh Mozzarella is a pasta filata cheese manufactured in various size and shapes and sold in brine in retail stores. One of the most common problems in Mozzarella is softening on the surface of the cheese and losing the structural integrity and shape (Luo et al., 2013). Soft and slimy surface negatively affect the appearance and consumer preference. Composition, $\mathrm{pH}$, rate of proteolysis, $\mathrm{Ca}$ and salt content and cheese manufacturing protocol are several factors that affect the final texture of cheeses (Lucey et al., 2003). For brined cheeses, brine composition influences the equilibrium between brine and cheese, and it is critical for controlling textural and rheological properties of cheeses (Geurts et al., 1972).

Fresh Mozzarella is a high moisture pasta filata cheese with milky buttery flavor originated in Italy (Luo et al., 2013). Although traditional Mozzarella cheese is manufactured from water buffalo, today large amount of Mozzarella cheese is produced from bovine milk due to its availability (Faccia et al., 2019). Generally, Mozzarella cheeses are produced as low moisture and high moisture Mozzarella. Low moisture Mozzarella is primarily produced for ingredient purposes such as topping for pizza. High moisture Mozzarella cheese is consumed as table cheese (Faccia et al., 2019). High moisture Mozzarella cheeses are produced in varying sizes. Recently production and consumption of perline (pearl size) Mozzarella has been increasing in Turkey. Perline Mozzarella cheeses are known as various names in Turkish market such as Süt Damlas1, Topi, Topik, and parents prefer these cheeses for their kids to get necessary cheese nutrients. As the size of perline Mozzarella is quite small considering bocconcini (bite-sized) and ovoline (egg-sized), migration of cheese solids into brine occurs much higher rate due to their larger surface area.

Fresh Mozzarella cheese is generally sold in preservative liquid (commonly water or brine) to preserve characteristics. Mass transfer between cheese and brine continue until reaching an equilibrium, thus product characteristics are prone to some changes during marketing (Mizuno et al., 2016). Laurenzio et al. (2008) reported that addition of polysaccharides into preservative liquid prevented the migration of cheese solid into the 
preservative media. Luo et al. (2013) reported that calcium in brine hinders the migration of salt from brine to cheese. Utilization of improper preservative liquid may lead to slimy surface on the cheese, cloudy and blurry appearance in the liquid or even complete solubilization of the cheese into brine which negatively affect consumer preference.

In this study, we wanted to investigate the effect of $\mathrm{Ca}$ concentration on perline Mozzarella cheese texture during 4 weeks storage. To our knowledge, this will be the first study investigating the brine $\mathrm{Ca}$ concentration in perline Mozzarella cheese.

\section{Materials and Methods}

\section{Cheese manufacture}

Perline Mozzarella cheeses were manufactured in a local dairy plant (Gunesoglu Sut, Sakarya, Turkey). Full fat milk $(\% 3.6 \pm 0.1$ fat, $\% 3.3 \pm 0.3$ protein, $\% 12.8 \pm 0.5$ total solids) was pasteurized at $74^{\circ} \mathrm{C}$ for $30 \mathrm{~s}$, cooled to $37^{\circ} \mathrm{C}$. Direct vat set thermophilic culture (TM1; MicroMilk; Cremosano, Italy) was added at the rate of $10 \mathrm{~g}$ for $450 \mathrm{~kg}$ of cheese milk. 30 minutes pre-ripening was applied to cheese milk to provide culture activity, then calf rennet (Naturen; Chr. Hansen, Istanbul, Turkey) was added to cheese milk at the rate of $63 \mathrm{~g}$ for $450 \mathrm{~kg}$ of cheese milk. The coagula were set around $50 \mathrm{~min}$ and cut after subjectively evaluated by the cheesemaker. Curd temperature in the vat was increased to $40^{\circ} \mathrm{C}$ in $30 \mathrm{~min}$. As $\mathrm{pH}$ reached 6.2, whey was drained and curd was transferred into a separate vat for acid development. As the curd $\mathrm{pH}$ reached $\mathrm{pH} 5.1$, the curd was milled and transferred to cooker strecher. Curd was streched in brine solution containing $3 \%$ salt and the temperature of $80^{\circ} \mathrm{C}$. Curd exited the cooker strecher at $66^{\circ} \mathrm{C}$ and entered ball making machine with diameter of $1 \mathrm{~cm}$. After the shapes were formed cheeses were cooled at $12^{\circ} \mathrm{C}$ water bath for $15 \mathrm{~min}$. The added $\mathrm{CaCl}_{2}$ concentrations of retail preservative liquid is given in Table 1. After manufacture, cheeses were stored in $4^{\circ} \mathrm{C}$.

\section{Compositional Analyses}

Cheese milk was analyzed for total solids (948.12; AOAC, 2007), protein (total percentage $\mathrm{N} \times 6.38$, Kjeldahl method; 991.20; AOAC, 2007), fat (2000.18; AOAC 2007), and pH (Hanna pH211; Hanna Instruments, Woonsocket, RI, USA) at the day of cheese manufacture. Cheeses were analyzed for total solids (941.08; AOAC, 2007), ash (945.46; AOAC 2007) and salt (975.20; AOAC 2007) at $2 \mathrm{wk}$ of storage. Retail brine was analyzed for protein (total percentage $\mathrm{N} \times 6.38$, Kjeldahl method; 991.20; AOAC, 2007) content during storage. Cheese $\mathrm{pH}$ was monitored using a spear-tip $\mathrm{pH}$ electrode (Inlab solid pro; Mettler Toledo, Columbus, OH, USA) during storage.

\section{Cheese Texture and Meltability}

Texture profile analysis (TPA) was carried out using a TA.XT2 Texture Analyzer (Texture Technologies Corp., Scarsdale, NY, USA). Perline Mozzarella samples were used as whole for textural analyses. Samples were compressed $30 \%$ in TPA test by a $75 \mathrm{~mm}$ aluminum cylinder probe with a cross-head speed of $0.8 \mathrm{~mm} \mathrm{~s}^{-1}$. All tests were performed at $5^{\circ} \mathrm{C}$ and replicated at least 5 times.
Cheese meltability was measured by Schreiber meltability test as described at (Voigt et al., 2012). Whole perline Mozzarella cheeses were placed into oven at $232^{\circ} \mathrm{C}$ for $5 \mathrm{~min}$ and cooled for $30 \mathrm{~min}$. Average distance values $(\mathrm{mm})$ of four readings of diameter at different places on the melted circles were averaged and recorded.

\section{Experimental Design and Statistical Analyses}

Perline Mozzarella cheeses were placed into the same retail brine ( $\mathrm{pH} 5.0$, salt 5.2\%) with 6 different added $\mathrm{CaCl}_{2}$ concentrations $(0,0.2,0.40 .6,0.8$ and $1.0 \%)$. Analysis of variance (ANOVA) testing was carried out by using JMP (11.0 version; SAS Institute Inc., Cary, NC, ABD). Data obtained from analyses were compared with Tukey-HSD multiple comparisons test, and significance was determined at $\mathrm{P}<0.05$. Pearson's correlation coefficients were estimated between various responses.

\section{Results and Discussion}

\section{Composition}

The composition of perline Mozzarella cheeses at $2 \mathrm{wk}$ of storage are given in Table 2. Increasing the $\mathrm{Ca}$ concentration decreased $\mathrm{pH}$ and moisture content of the cheeses. Increase in the ash content of the cheeses can be explained by the increase in total solid content of the cheeses with increased $\mathrm{Ca}$ concentration in brine. However, decrease in the cheese $\mathrm{pH}$ with increasing $\mathrm{Ca}$ concentrations of brine was unexpected. One way to explain the decrease in the cheese $\mathrm{pH}$ with increased brine $\mathrm{Ca}$ concentration is that cheeses lost structural integrity at low brine $\mathrm{Ca}$ concentration and solubilized (Figure 1). Similarly, Mizuno et al. (2016) reported that increase in brine $\mathrm{Ca}$ concentration in ovoline Mozzarella decreased cheese $\mathrm{pH}$. The solubilization of cheeses opened the protein network to brine, which lead to increased solubilization of insoluble $\mathrm{Ca}$ (INSOL Ca) phosphate. It is a well-known phenomenon that as protein bound $\mathrm{Ca}$ solubilized from the caseins, phosphate buffers and increase pH (Lucey et al., 1993; Lucey et al., 2003; Salaun et al., 2005). Previous studies indicated that decrease in brine $\mathrm{Ca}$ concentration led to solubilization of INSOL Ca concentration in cheese (Faccia et al., 2019; Mizuno et al., 2016).

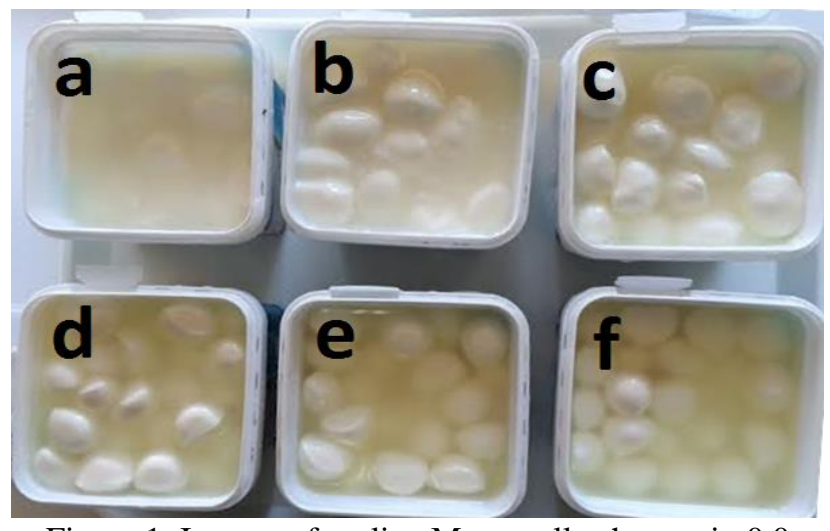

Figure 1. Images of perline Mozzarella cheeses in 0.0 (control) (a), 0.2 (b), 0.4 (c), 0.6 (d), 0.8 (e), and 1.0\% (f) $\mathrm{CaCl}_{2}$ containing brines at $2 \mathrm{wk}$ of storage. 


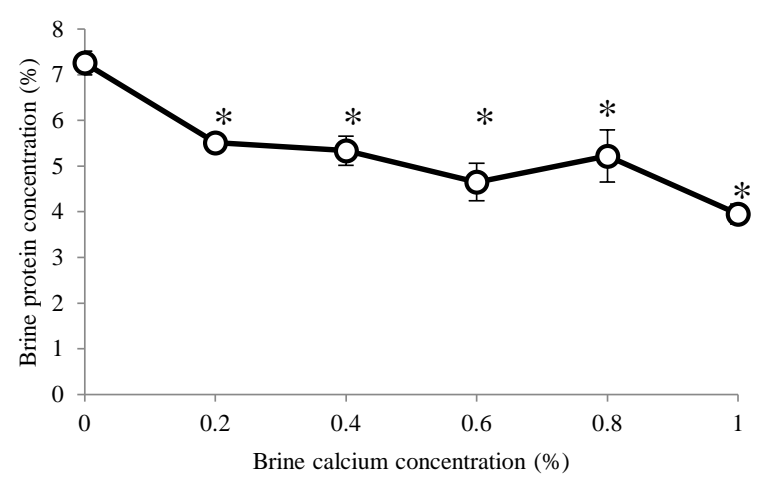

Figure 2. Protein contents of brines at various brine calcium concentrations at $2 \mathrm{wk}$ of storage. $(*$ denotes significantly $(\mathrm{P}<0.05)$ different from control)

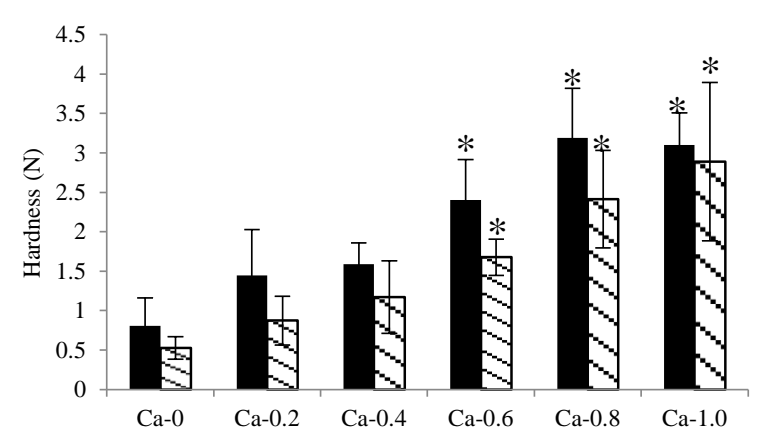

Figure 3. Hardness of perline Mozzarella cheeses at 0.0 (control) (Ca-0.0), 0.2 (Ca-0.2), $0.4(\mathrm{Ca}-0.4), 0.6(\mathrm{Ca}-$ $0.6), 0.8(\mathrm{Ca}-0.8)$, and $1.0 \%(\mathrm{Ca}-1.0)$ calcium containing brines at $2(\square)$ and $4(\square)$ wk of storage. $(*$ denotes significantly $(\mathrm{P}<0.05)$ different from control)

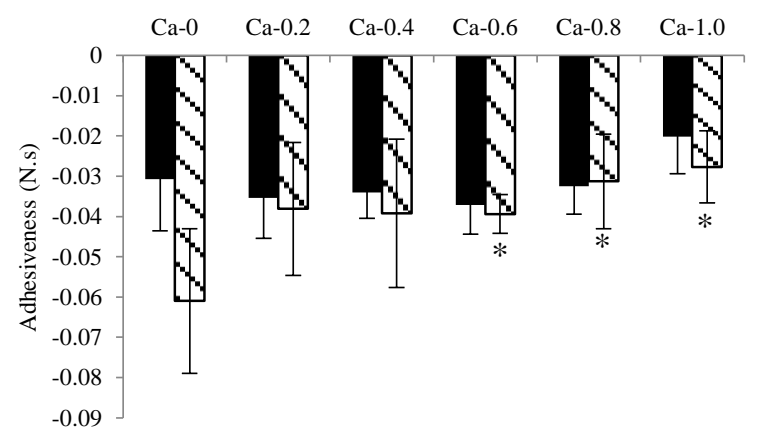

Figure 4. Adhesiveness of perline Mozzarella cheeses at 0.0 (control) (Ca-0.0), 0.2 (Ca-0.2), 0.4 (Ca-0.4), 0.6 (Ca$0.6), 0.8(\mathrm{Ca}-0.8)$, and $1.0 \%$ (Ca-1.0) calcium containing brines at $2(\square)$ and $4(\Delta)$ wk of storage.

$(*$ denotes significantly $(\mathrm{P}<0.05)$ different from control)

There was a negative correlation $\left(\mathrm{R}^{2}=0.92, \mathrm{P}<0.05\right)$ between brine $\mathrm{Ca}$ concentration and the moisture content of the cheeses, in other words, increase in the brine $\mathrm{Ca}$ concentration decreased the cheese moisture content. Geurts et al. (1972) conducted one of the first studies on the effect of brine $\mathrm{Ca}$ concentration on cheese surface. They reported that utilization of $\mathrm{Ca}$ in brine used in Gouda cheese manufacture prevented soft rind defect and the moisture content of the Gouda cheeses manufactured in Ca containing brine was lower. Previous studies on Mozzarella cheese were also reported that increase in brine $\mathrm{Ca}$ concentration decreased the moisture content of cheese (Luo et al.,2013; Mizuno et al., 2016). The changes between brine $\mathrm{Ca}$ concentration and brine protein concentration are given in Figure 2. As the structural integrity of the cheeses is lost and cheese protein diffuses into brine. The brine $\mathrm{Ca}$ concentration and brine protein concentration were negatively correlated $\left(\mathrm{R}^{2}=0.87, \mathrm{P}<0.05\right)$, i.e., as the brine $\mathrm{Ca}$ concentration increased the protein content diffused to the retail brine decreased. This result suggests that even small concentration of $\mathrm{Ca}$ in brine had a great impact on structural integrity of perline Mozzarella cheeses compared to control (without $\mathrm{Ca}$ addition) brine. Salt content of perline Mozzarella cheeses were uneffected by the brine $\mathrm{Ca}$ concentration $(\mathrm{P}>0.05)$. Previous studies suggested that water channels between protein fibers that occurs during pasta-filata process were primarily responsible for salt diffusion and these channels were became less visible during storage due to protein hydration in Mozzarella cheese (Kuo et al., 2003; Sheehan et al., 2005; McMahon et al., 1999). Luo et al. (2013) reported that brine Ca interfered with salt diffusion from brine into Mozzarella cheeses. Salt diffusion and protein hydration occur in cheeses in the first 2 wk of storage, thus we believe that we did not observe differences in the salt content between the cheeses of storage and our experimental cheeses were analyzed for salt at 2 wk (Metzger et al., 2001; Guo and Kindstead, 1995).

\section{Cheese Texture}

Hardness of cheese samples increased with the increase of Ca concentration in brine (Figure 3.). Moisture content of cheese directly influences the cheese texture. Previous studies reported that increase in cheese moisture decreases cheese hardness (Gunasekaran and Ak, 2003). Our textural results are highly correlated with cheese moisture. Cheese hardness and cheese moisture results were negatively correlated at $2 \mathrm{wk}\left(\mathrm{R}^{2}=0.91, \mathrm{P}<0.05\right)$ and $4 \mathrm{wk}$ of storage $\left(\mathrm{R}^{2}=0.87, \mathrm{P}<0.05\right)$, i.e., increase in Ca concentration of the brine decreased the moisture content of the cheeses, thus cheese hardness increased with brine $\mathrm{Ca}$ concentration. Cheeses manufactured with higher than $0.6 \%$ brine $\mathrm{Ca}$ concentration exhibited significantly $(\mathrm{P}<0.05)$ higher hardness at 2 and $4 \mathrm{wk}$ of storage. Cheese adhesiveness did not exhibit significant differences at $2 \mathrm{wk}$ of storage (Figure 4.). However, adhesiveness of cheeses manufactured in brine higher than $0.6 \% \mathrm{Ca}$ was significantly lower than control at $4 \mathrm{wk}$ of storage. McMahon et al. (2005) reported that increase in $\mathrm{Ca}$ concentration in block type nonfat Mozzarella cheese did not influence cheese adhesiveness; however, similar to our results they also reported that increase in moisture content of cheese significantly increased cheese adhesiveness. Springiness and cohesiveness were not influenced with brine $\mathrm{Ca}$ concentration (results not shown).

Table 1. Composition of brines prepared for perline Mozzarella cheeses.

\begin{tabular}{l|ccc}
\hline \multicolumn{1}{c}{ Sample } & $\mathrm{CaCl}_{2}(\%)$ & $\mathrm{pH}$ & Salt (\%) \\
\hline $\mathrm{Ca}-0$ (Control) & $0^{*}$ & 5.0 & 5.2 \\
$\mathrm{Ca}-0.2$ & 0.2 & 5.0 & 5.2 \\
$\mathrm{Ca}-0.4$ & 0.4 & 5.0 & 5.2 \\
$\mathrm{Ca}-0.6$ & 0.6 & 5.0 & 5.2 \\
$\mathrm{Ca}-0.8$ & 0.8 & 5.0 & 5.2 \\
$\mathrm{Ca}-1.0$ & 1.0 & 5.0 & 5.2 \\
\hline \multicolumn{2}{l}{ *Without calcium addition }
\end{tabular}


Table 2. Moisture, ash, salt and $\mathrm{pH}$ values of perline Mozzarella cheeses at 2 wk of storage.

\begin{tabular}{l|ccc}
\hline \multicolumn{1}{c|}{ Sample } & Moisture (\%) & Ash (\%) Salt (\%) & pH \\
\hline Ca-0 (Control) & $82.1 \pm 2.4^{\mathrm{a}}$ & $4.0 \pm 0.22 .6 \pm 0.25 .8 \pm 0.0^{\mathrm{a}}$ \\
$\mathrm{Ca}-0.2$ & $80.6 \pm 1.7^{\mathrm{a}}$ & $4.2 \pm 0.22 .6 \pm 0.25 .8 \pm 0.0^{\mathrm{a}}$ \\
$\mathrm{Ca}-0.4$ & $77.1 \pm 1.3^{\mathrm{b}}$ & $4.2 \pm 0.32 .7 \pm 0.45 .8 \pm 0.1^{\mathrm{a}}$ \\
$\mathrm{Ca}-0.6$ & $71.4 \pm 1.3^{\mathrm{c}}$ & $4.2 \pm 0.22 .6 \pm 0.35 .8 \pm 0.1^{\mathrm{a}}$ \\
$\mathrm{Ca}-0.8$ & $73.1 \pm 3.1^{\mathrm{c}}$ & $4.2 \pm 0.32 .6 \pm 0.15 .7 \pm 0.0^{\mathrm{b}}$ \\
$\mathrm{Ca}-1.0$ & $71.9 \pm 1.1^{\mathrm{c}}$ & $4.3 \pm 0.32 .6 \pm 0.25 .5 \pm 0.1^{\mathrm{c}}$ \\
\hline
\end{tabular}

${ }^{\mathrm{a}-\mathrm{c} M e a n s}$ within the same column not sharing a common superscript differ $(\mathrm{P}<0.05)$.

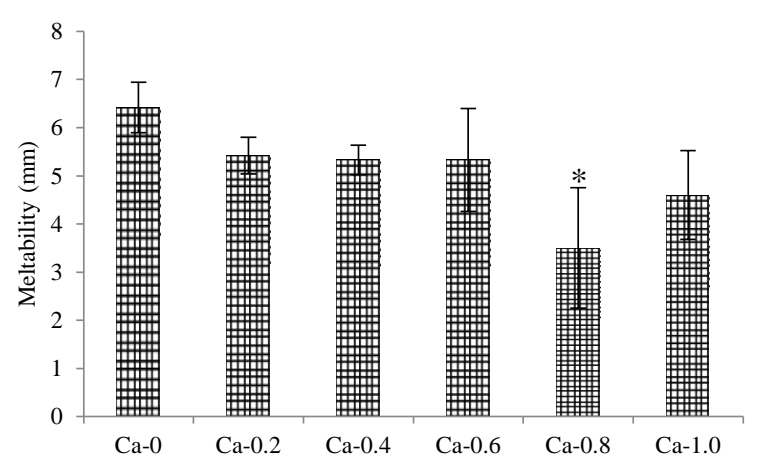

Figure 5. Meltability of perline Mozzarella cheeses at 0.0 (control) (Ca-0.0), 0.2 (Ca-0.2), 0.4 (Ca-0.4), 0.6 (Ca$0.6), 0.8(\mathrm{Ca}-0.8)$, and $1.0 \%$ (Ca-1.0) calcium containing brines at $2 \mathrm{wk}$ of storage.

$(*$ denotes significantly $(\mathrm{P}<0.05)$ different from control)

\section{Cheese Meltability}

Cheese meltability results obtained by Schreiber test is given in Figure 5. There was a negative correlation between brine Ca concentration and cheese meltability $\left(\mathrm{R}^{2}\right.$ $=-0.81, \mathrm{P}<0.05)$, i.e., increase in brine $\mathrm{Ca}$ concentration decreased cheese meltability. Cheeses stored in $0.8 \% \mathrm{Ca}$ brine exhibited significantly lower meltability than control $(\mathrm{P}<0.05)$. Lucey et al. (2003) reported that moisture content directly influences the meltability of cheese. McMahon et al. (2005) reported that increase Ca concentration on block type nonfat Mozzarella decreased cheese meltability. Thus, the lower moisture content of cheeses at high Ca containing brine must be responsible for low melting observed. There are two main forces that affects casein micelles; hydrophobic interactions and electrostatic repulsion (Horne, 1998). As INSOL Ca in cheese solubilizes negatively charged phosphate groups in protein network weakens the structure, leading to higher meltability. Excessive solubilization of INSOL Ca at $\mathrm{pH}$ values closer to the isoelectric $\mathrm{pH}$ of caseins lead to increase in meltability due to increased hydrophobic interaction between caseins. Calcium in the soluble phase of the brine prevents the solubilization of INSOL Ca, leading to more integral protein matrix (Lucey et al., 2003). Higher brine $\mathrm{Ca}$ concentration may also impair solubilization of INSOL $\mathrm{Ca}$ in our cheeses, leading to less meltability.

\section{Conclusion}

Increase in the Ca concentration of the brine decreased the protein diffusion from cheese to brine, prevented blurry appearance of brine and improved textural properties. Even small amounts of $\mathrm{Ca}$ in brine is very effective to prevent solids loss from cheese into brine. Informal sensory evaluation revealed that brines containing $1 \% \mathrm{Ca}$ resulted in unwanted bitter and metallic flavor (results not shown). In conclusion, utilization of $\mathrm{Ca}$ higher than $0.6 \%$ in retail brines prevent solubilization/melting of the perline Mozzarella during 1 mo of storage. We believe that results of this study will be helpful for local and international perline Mozzarella producers.

\section{Acknowledgements}

We would like to thank to Güneşoğlu Süt A.Ş. for allowing us to use their facilities and providing us the experimental cheeses. We also would like to thank to undergraduate student Asiye Araz for all her help during the experimental analyses.

\section{References}

AOAC, 2007. Official Methods of Analysis. 17th ed. Association of Official Analytical Chemists International, Arlington, VA. ISBN: 09355847819780935584783

Faccia M, Gambacorta G, Natrella G, Caponio F. 2019. Shelf-life extension of Italian mozzarella by use of calcium lactate buffered brine. Food Control. 100:287-91. doi: 10.1016/j.foodcont.2019.02.002

Geurts TJ, Walstra P, Mulder H. 1972. Brine composition and the prevention of the defect 'soft rind'in cheese. Netherlands Milk and Dairy Journal. 26:168-79. doi: not available

Gunasekaran S, Ak MM. 2002. Cheese rheology and texture. CRC press. ISBN: 978-1587160219

Guo MR, Kindstedt PS. 1995. Age-related changes in the water phase of Mozzarella cheese. Journal of Dairy Science. 78(10):2099-107. doi: 10.3168/jds.S0022-0302(95)76836-9

Horne DS. 1998. Casein interactions: casting light on the black boxes, the structure in dairy products. International Dairy Journal. 8(3):171-7. doi: 10.1016/S0958-6946(98)00040-5

Kuo MI, Anderson ME, Gunasekaran S. 2003. Determining effects of freezing on pasta filata and non-pasta filata Mozzarella cheeses by nuclear magnetic resonance imaging. Journal of dairy science. 86(8):2525-36. doi: 10.3168/jds.S0022-0302(03)73847-8

Laurienzo P, Malinconico M, Mazzarella G, Petitto F, Piciocchi N, Stefanile R, Volpe MG. 2008. Water buffalo mozzarella cheese stored in polysaccharide-based gels: correlation between prolongation of the shelf-life and physicochemical parameters. Journal of dairy science. 91(4):1317-24. doi: 10.3168/jds.2007-0482

Lucey JA, Hauth B, Gorry C, Fox PF. 1993. The acid-base buffering properties of milk. Milchwissenschaft. 48(5):268-72. doi: not available

Lucey JA, Johnson ME, Horne DS. 2003. Invited review: perspectives on the basis of the rheology and texture properties of cheese. Journal of Dairy Science. 86(9): 27252743. doi: 10.3168/jds.S0022-0302(03)73869-7

Luo J, Pan T, Guo HY, Ren FZ. 2013. Effect of calcium in brine on salt diffusion and water distribution of Mozzarella cheese during brining. Journal of dairy science. 96(2): 824-831. doi: org/10.3168/jds.2012-5888

McMahon DJ, Fife RL, Oberg CJ. 1999. Water partitioning in Mozzarella cheese and its relationship to cheese meltability. Journal of Dairy Science. 82(7):1361-9. doi: 10.3168/jds. S0022-0302(99)75361-0

McMahon DJ, Paulson B, Oberg CJ. 2005. Influence of calcium, $\mathrm{pH}$, and moisture on protein matrix structure and functionality in direct-acidified nonfat Mozzarella cheese. Journal of Dairy Science. 88(11):3754-63. doi: 10.3168/jds. S0022-0302(05)73061-7 
Metzger LE, Barbano DM, Kindstedt PS, Guo MR. 2001. Effect of milk preacidification on low fat Mozzarella cheese: II. Chemical and functional properties during storage. Journal of Dairy Science. 84(6):1348-56. doi: 10.3168/jds.S00220302(01)70165-8

Mizuno R, Abe T, Koishihara H, Okawa T. 2016. The Effect of Preservative Liquid Composition on Physicochemical Properties of Mozzarella Cheese. Food Science and Technology Research. 22(2):261-6. doi: 10.3136/fstr.22.261

Salaün F, Mietton B, Gaucheron F. 2005. Buffering capacity of dairy products. International Dairy Journal. 15(2):95-109. doi:10.1016/j.idairyj.2004.06.007
Sheehan JJ, Huppertz T, Hayes MG, Kelly AL, Beresford TP, Guinee TP. 2005. High pressure treatment of reduced-fat Mozzarella cheese: Effects on functional and rheological properties. Innovative Food Science and Emerging Technologies. 6(1):73-81. doi:10.1016/j.ifset.2004.10.003

Voigt DD, Chevalier F, Donaghy JA, Patterson MF, Qian MC, Kelly AL. 2012. Effect of high-pressure treatment of milk for cheese manufacture on proteolysis, lipolysis, texture and functionality of Cheddar cheese during ripening. Innovative Food Science and Emerging Technologies. 13:23-30. doi: 10.1016/j.ifset.2011.10.004 